Diachok, O.M., Kuziv, M.P., Volska, S.O., \& Datsiuk, N.M. (2022). Protection of cultural heritage. Yazlovets Palace. Culture and arts in the context of world cultural heritage. Klironomy, 1 (4), 7-15. Ostrava: Tuculart Edition.

DOI: $10.47451 /$ her2022-02-02

The paper will be published in Crossref, Internet Archive, ICI Copernicus, Google Scholar, Academic Resource Index ResearchBib, JGate, ISI, eLibrary, Ukrainian National Library databases.

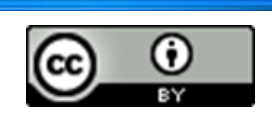

Oksana Myronivna Diachok, Doctor of Architecture, Associate Professor, Professor of the Department of Fine Arts, Design and Methods of Their Teaching, Ternopil Volodymyr Hnatiuk National Pedagogical University, Ternopil, Ukraine ORCID: 0000-0002-5808-6826. ResearcherID: I-7798-2018

Mykhaylo Petrovych Kuziv, Associate Professor of the Department of Fine Arts, Design and Methods of Their Teaching, Ternopil Volodymyr Hnatiuk National Pedagogical University, Ternopil, Ukraine.

ORCID: 0000-0003-1928-734X

Svitlana Oleksiivna Volska, Associate Professor of the Department of Fine Arts, Design and Methods of Their Teaching, Ternopil Volodymyr Hnatiuk National Pedagogical University, Ternopil, Ukraine.

ORCID: 0000-0002-2775-5716

Nataliia Mykhaylivna Datsiuk, Post-graduate student of the Department of Design and Theory of Art, Vasyl Stefanyk Precarpathian National University, Ivano-Frankivsk, Ukraine.

ORCID: 0000-0003-2548-3638

\title{
Protection of cultural heritage. Yazlovets Palace
}

Abstract: The article examines the history of formation and architectural planning of the palace complex in the village of Yazlovets, Ternopil region. The monument of architecture and urban planning of national importance has partially lost its suitability for operation, needs urgent restoration and renovation, which is confirmed by field inspections. During its long history, the palace has undergone many reconstructions, prosperity, destruction and restoration, was at the centre of historical and political events in the region. Built as a defence complex, its buildings performed ideological, cultural, social, sacred functions. Today, the complex still has significant historical and cultural value, contains valuable artistic artifacts and attracts pilgrims and tourists from around the world. The palace gives ideological colour to the small town, is its bright dominant. The castle in the village of Yazlovets became part of the Ternopil Castles National Reserve. In the course of the research a historical reference about the object of cultural heritage was made, a recommendation on the use of the palace complex was given. The purpose of the article is to introduce into scientific circulation updated data on the valuable monument of urban planning and architecture of Ternopil region - Palace of the 17th and 18th centuries in the village of Yazlovets.

Key words: Yazlovets, Ternopil region, cultural heritage, palace, castle, restoration.

\section{Introduction}

The level of development of society, its maturity can be determined by analyzing its attitude to cultural heritage and preservation of its monuments. State policy of Ukraine in the field of cultural heritage protection defines a number of tasks for scientists, security organizations, 
including: implementation of comprehensive measures for accounting of cultural heritage sites, their scientific study, classification, state registration by entering in the State Register of Immovable Monuments of Ukraine checking the condition (inventory) of objects in order to quickly respond to various threats to them. The most valuable attractions can be involved in national and international tourist routes.

In modern conditions, the requirements for information about the cultural heritage site, necessary for rapid response to the threat to the object during construction, reclamation, road, earthworks in their protection zones, in the historical areas of settlements have increased. In this regard, there is a need for a continuous certification of cultural heritage sites (archaeological, historical, monumental art, architecture and urban planning, landscape and garden and park art), introducing an electronic form of storage of information about them, which will make the information about these objects more accessible.

The role of monastic complexes in the formation of silhouettes of cities and villages of Ukraine was studied by Rudnytsky A.M., Chen L.Ya. (2008), historical and architectural analysis of individual sacred monuments was conducted by Lohvyn H. (1968), Bevz M.V. (2001), Vecherskyy V. (2008), Vodzinskyy, E. (1996). However, there is still no comprehensive modern study of the Yazlovets Palace Complex in art history. All of the above indicates the relevance of this work.

Among the valuable monuments of cultural heritage of Ternopil region, which require inventory and certification, is an architectural monument of national importance - the Palace of the 17th and 18th centuries in the village of Yazlovets, Chortkiv district (preservation No. 1575), which is the object of this study.

The purpose of the article is to introduce into scientific circulation updated data on the valuable monument of urban planning and architecture of Ternopil region - Palace of the 17th and 18th centuries in the village of Yazlovets. To achieve this goal, it is necessary to solve a number of tasks: to make an inventory of the monument, to supplement the historical information about the complex, to describe the object and its technical condition, to give a recommendation on the cultural heritage site.

A set of theoretical and empirical scientific methods was used to implement the tasks. In particular, analysis, generalization, description, photo fixation, dimensional drawings, etc. Research materials can be used for certification of cultural heritage sites, in tourism, teaching, in further research.

\section{Main part}

The territory of the Yazlovets Palace Complex occupies the top of an elongated wooded hill with steep slopes, which is surrounded by a loop from the north, west and south of the Vilkhovets riverbed. The monument is an authentic example of the defensive and palace architecture of Podillya of the 17th and 18th centuries. In general, the palace has retained its shape and spatial structure. Some parts of the palace (corner rooms at the junction of the central part and the side wings) are rebuilt defensive towers of the Lower Castle of the 17th century, and the three-storey part with through passage - the former entrance gate. Significant historical and cultural value is the plastic carved stone decoration of the facades of the three-story central part in the Renaissance and Baroque style. These are portals, heraldic cartouches on the 
tympanums of the pediments, figured consoles of the balcony, a sculpture of the saint (Diachok, 2018).

However, today there are a number of negative factors that affect the monument. The inspection of the object revealed: the general technical condition of the central part and the southern wing of the palace is satisfactory; the northern wing of the palace is unsuitable for normal technical operation. The lack of appropriate landscaping is also obvious. The existing outbuildings next to the monument and individual buildings erected during the Soviet period are dissonant. Thus, the monument needs restoration work for quality operation of buildings and elimination of threats to their existence.

\section{Historical information about the object}

Yazlovets lies in a canyon covered with forest in the valley of the river Vilkhovets, $14 \mathrm{~km}$ southeast of the town of Buchach. Today it is a small settlement (in 2007 the population was 617 people), which belongs to the Buchach town community. However, for most of its history, Yazlovets had the status of a town. Yazlovets was first mentioned in documents of the first half of the 14th century. In the middle of the 15th century, due to its advantageous location near the trade routes between the Kingdom of Poland and the Principality of Moldavia, Yazlovets was a significant trade center (Vodsynskyy, 1990).

The history of the Yazlovets Palace is inextricably linked with the Old (High) Castle, located on a steep hill next to the palace. This castle was first mentioned in 1436 as the residence of the noble family of the Buchach coat of arms Abdank, it was of such great strategic importance that it was considered the "Key of Podillya" (Rybchynskyy, 2005). It is assumed that the first stage of construction of the Old Castle in Yazlivka falls on the second half of the 14th and early 15th century. At that time, it was a small pentagonal stone fortification, which initially occupied half the area of ruins that have survived to our time. Three walls of the castle (northern, southern and eastern) delineated the rectangular in plan area of the castle yard, on the west side of the two castle walls converged at right angles, forming a wedge. At the peak of the wedge a square tower in plan was built, which at that time was probably the only tower of the castle. The gate was arranged in the north-western wall. On three sides (north, west and east) access to the castle was hampered by steep slopes of the hill, on the east side a ditch that cut off the castle from the main massif of an elongated hill was dug.

In the first half of the 15th century, under Theodoric of Buchach-Yazlovets, the castle was rebuilt. The moat, which protected it from the east, was filled in to expand the fortifications. The rebuilt castle consisted of two connected pentagons - the old western and the new eastern. The thickness of the castle walls reached 2 meters. The wedge in the eastern part of the castle fortifications was also crowned by a square tower in plan. On the site of the moat and the old defensive wall, the need for which disappeared, a living space was built, which divided the castle into two courtyards - the western (old pentagon) and eastern (new pentagon). A new defensive moat was dug on the eastern part of the castle.

In the middle of the 16th century, the Grand Crown Hetman Yuriy (Jerzy) of Yazlovets carried out work on the modernization and reconstruction of old fortifications. On the south-western side of the castle, a new castle gate was built, to protect which a powerful pentagonal gate tower with carved 
Renaissance portals was built. Access to the castle was provided by a long sloping wooden bridge on the west side.

The next construction phase took place in 1644-1659, when the owner of the castle, Grand Crown Hetman Stanislaw Koniecpolski (1591-1646) and his son Alexander (1620-1659) modernized and significantly expanded the castle. During this period, Yazlovets Castle received a second line of stone fortifications, and on the western side the Lower (New) Castle was built, which was later rebuilt into a palace. A moat was dug on the outside of the western wall of the Lower Castle, over which the bridge leading to the gate tower was overturned. Thus, the Yazlovets Palace was originally a casemate fortification of the Lower Castle with two corner bastions.

On January 9, 1672, Yazlovets was visited by atraveler from Friesland Ulrich von Werdum, who described the local stronghold in his diary as follows: "The castle rises to a cannon shot west of the city on a separate hill, which reaches across the mountain into a long valley. It is a large, well-built in Italian way with high walls, a flat roof and many chimneys, but already halfdevastated.

In the same year, the Ottoman Empire started a war against the Polish-Lithuanian Commonwealth and invaded Polish-controlled lands. In September-October, the Turks captured Yazlovets and the castle, where a garrison led by Pasha Osman was established. Eventually, in the first days of December 1673, under pressure from the Poles, led by Jan Koniecpolski, the Turks were forced to leave Yazlovets (Yazlovets Palace).

The Buchach Peace Treaty of October 18, 1672, summed up the first stage of the PolishTurkish War, but was not approved by the Polish Sejm. In fact, the Polish side refused to continue to comply with the terms of this agreement and therefore the war resumed. In 1675, a large Turkish army led by Pasha Ibrahim Shishman launched a large-scale offensive on Lviv, destroying castles along the way and devastating cities. During this offensive, Yazlovets was captured by the Turks and surrendered to the enemy without a fight. Yazlovets Castle, which became the main stronghold of the Turkish garrison, was maintained in good condition and even further strengthened.

The liberation of Yazlovets from Turkish occupation took place after the famous Battle of Vienna on September 12, 1683, during which the Holy League army led by Polish King Jan Sobieski defeated the Turks, who began to liberate the Ottoman lands of the Commonwealth. During this period, Yazlovets was also released (Horodyskyy \& Zinchyshyn, 1998).

In 1699, the Karlovy Vary Peace Treaty was concluded between the Ottoman Empire and the Holy League (Austria, Venice, the Polish-Lithuanian Commonwealth, and the Muscovy), under which the Polish-Lithuanian Commonwealth officially regained control of Podillya. Yazlovets finally returned to the rule of the Poles. However, the damage caused by the war and subsequent Turkish occupation was irreparable. The city was no longer destined to regain its former influence and power. Yazlovets fell into disrepair, and with it the castle did (Beva, 2001).

At the beginning of the 18th century Yazlovets Castle was still considered an important strategic point and a significant fortification. This is evidenced by the fact that in this castle in 1711 a meeting took place between representatives of the Commonwealth, the Ottoman Empire and the Crimean Khanate. This meeting summed up the centuries-old conflict, and since then 
neither Turks nor their Tatar vassals have approached the borders of the Polish-Lithuanian Commonwealth (Rybcaynskyy, 2005).

From 1723 to 1745 Yazlovets and the castle were owned by the Lubomyrski family. In 1747, Yazlovets was acquired by the Cracow castellan Stanislaw Poniatowski (1676-1762) - the father of the future King of the Polish-Lithuanian Commonwealth Stanislaw August (1732-1798). He did not restore the abandoned upper castle, but instead rebuilt the lower castle, turning it into a palace. The stone of the old fortress and the new brick were used for this purpose. Poniatowski completed two side wings, which absorbed the defensive walls of the lower castle. The residence turned into a U-shaped complex, which formed a courtyard-courier in the direction of the castle. On the other side of the palace was a park, with which the courtyard was connected by a through arched passage located on the axis of the palace. This through passage in the 17th century served as the main entrance to the castle (Heritage. Yazlovets. Castle).

In the second half of the 18th century Yazlovets lost the status of a trading town. Since the main residence of the magnates was located in the palace, the Old Castle fell into disrepair. After 1777, it became the property of the Potocki family, and its last inhabitants left the Old Castle. The unattended stronghold was looted and left to fend for itself.

The next owners of Yazlovets Castle - Krzysztof Grudnicki in 1800-1815 and Victor Blazowski in 1816-1841 - also did not care about preserving the ancient building. And only the son of the latter, Krzysztof Blazowski, although he did not seek to restore the Old Castle, but renovated the palace of the New Castle and made many efforts to restore the trade and economic potential of the town. Finally, in 1863, Christopher Blazowski transferred the palace to the convent of the Congregation of the Sisters of the Immaculate Conception of the Blessed Virgin Mary, which was founded in 1854 in Rome. Marcelina Darovska became the founder of the monastery in Yazlovets. Marcelina later bought the palace and it became the property of the monastery. A school for girls and a free school for local children were opened at the monastery. In 1862-1863 the ballroom of the palace was converted into a chapel. in 1883 a marble figure of the Immaculate Virgin Mary was brought from Rome and christened as "Yazlivetska".

In 1873, a large underground chapel-tomb was built in the middle of the park, which has no analogues in Ukraine. 84 sisters are buried in the crypt, including the founder of the monastery Marcelina, who died in 1911. The chapel is rectangular in plan with a long corridor, covered with a cylindrical vault with light lanterns protruding to the ground. Several tiers of burial chambers are located on both sides of the corridor (Diachok, 2017).

It is known that during the First World War a large part of the palace was adapted for a military hospital. In 1916 the front line passed through Yazlovets. During this period, the palace was occupied first by the Hungarian military headquarters, then by the headquarters of Russian military units, and later the Prussian units chose the palace as a headquarters. During 1918-1919, the castle palace witnessed several clashes between Ukrainians and Poles, conflicting on national grounds (Dyachok, 2021:219-221).

In the 1930 s, a well-known Polish specialist in the history of architecture, Bohdan Gerken (1904-1979), conducted thorough research on the territory of Yazlovets Castle. Based on these studies, a monograph was created that describes in detail the main stages of construction of the castle (Fig. 1). 
The monastery existed in the palace building until 1947 and was closed by the Soviet authorities. The former monastery housed first a zootechnic school and later a regional pulmonology sanatorium.

In 1983, a group of architects from the Ukrainian Western Project Restoration Institute, based on historical information and architectural and archaeological surveys, developed a preliminary design for the restoration and adaptation of Yazlovets Castle buildings for a cultural and tourist centre. The project provided for the conservation and partial restoration of the Upper Castle, the restoration and partial reconstruction of the Lower Castle and the restoration of the castle park. The project was not implemented.

In 1996, a nunnery resumed its activities in the central part and south wing of the palace. The north wing continued to be used as a hospital. On November 5, 2008, according to the order of the Cabinet of Ministers of Ukraine, the castle in the village of Yazlovets became a part of the National Reserve "Ternopil Castles" (SHAR "Ternopil Castles").

Today, the palace houses the convent of the Congregation of the Sisters of the Immaculate Conception of the Blessed Virgin Mary. On the second floor of the monastery, there is the house church and museum of Blessed Marceline Darowska. After the closure of the hospital, the north wing of the palace has not been used. Therefore, the central and southern part of the monument, where the nunnery is located, is in a satisfactory condition, the northern part is unfitted for normal use. The old castle next to the palace has survived in ruins (Fig. 2).

Object description. The castle and the palace are bright spatial dominants in the development of the village of Yazlovets. The territory of the monument is partially fenced with a low stone wall. Between the palace and the ruins of the castle are a number of garages and outbuildings. To the west of the monument is a palace park with alleys, in the depths of which, above the edge of the cape, is the tomb of the founder of the Yazlovets monastery - Blessed Marcelina Darowska. The area of the protection zone is 3.77 hectares. (Fig. 3).

The palace is built of stone and brick, U-shaped in plan, symmetrical. The large front yardcourd'honneur opens towards the ruins of Yazlovets Castle of the 15th century. and is connected by a through passage with a park located on the axis of the palace. Most of the building is twostorey, covered with hip roofs of complex configuration. The central part of the building (above the through passage) has three floors, covered with a gabled roof and completed on both facades with triangular pediments with coats of arms and attributes of heraldic themes in the tympana.

The passage, which in the 17th century served as the main entrance to the castle, is covered with a semicircular vault with strips (Fig. 4). On the side of the main and park facades, it is decorated with portals that combine Renaissance and Baroque features.

The portal of the central entrance is decorated on the sides with pilasters, which have a relief image of a flowerpot. The archivolt of the arch is decorated with embossed leaf rosettes. The entrance arch is framed by fluted columns, the lower part of which is decorated with carved flowers and ovals. The columns stand on massive plinths decorated with stylized lion masks and floral ornaments (Fig. 4). The columns are completed with capitals decorated with stylized acanthus leaves. Consoles are figured above the portal of the courtyard facade of the palace, which are decorated with mascarons in the form of stylized male heads. The walls on the low plinth are finished with profiled cornices. 
The list of cultural values in the monument: the portal of the park facade (middle of the 17th century) (material - sandstone), decorated with Renaissance and Baroque white stone carvings; a sculpture of an unknown saint (18th century) (material - sandstone), placed above the entrance portal on the park side, in a semicircular niche and depicts a man with a child in his left hand, a palm branch in his right hand; heraldic cartouche (18th century) (material - sandstone), located above the entrance to the palace from the park; heraldic cartouche (18th century) (material - sandstone), located above the entrance to the palace from the courtyard; portal of the courtyard facade (middle of the 17th century) (material - sandstone), decorated with Renaissance and Baroque white stone carvings; consoles (middle of the 17th century) (material - sandstone), located above the portal of the courtyard facade of the palace, figured, decorated with mascarons; wrought iron lattice (second half of the 18th century) (material - Iron), located in the window of the southern building of the palace from the courtyard.

The list of cultural values in the monument: the portal of the park facade (middle of the 17th century) (material - sandstone), decorated with Renaissance and Baroque white stone carvings; a sculpture of an unknown saint (18th century) (material - sandstone), placed above the entrance portal on the park side, in a semicircular niche and depicts a man with a child in his left hand, a palm branch in his right hand; heraldic cartouche (18th century) (material - sandstone), located above the entrance to the palace from the park; heraldic cartouche (18th century) (material - sandstone), located above the entrance to the palace from the courtyard; portal of the courtyard facade (middle of the 17th century) (material - sandstone), decorated with Renaissance and Baroque white stone carvings; consoles (middle of the 17th century) (material - sandstone), located above the portal of the courtyard facade of the palace, figured, decorated with mascarons; wrought iron lattice (second half of the 18th century) (material - Iron), located in the window of the southern building of the palace from the courtyard.

\section{Conclusion}

After analysing the history of construction and spatial planning structure of the Yazlovets Castle and Palace complex, as well as after the inventory, it can be stated that the buildings are still a valuable monument of urban planning and architecture in need of restoration and renovation.

For a long time, the buildings performed a defensive, later secular function, and after the transfer of part of the monastery buildings - sacred, cultural, political. Part of the palace was transferred to a hospital during the Soviet era and is in an unusable condition due to careless treatment to the monument. The palace contains valuable artifacts, is an important dominant in the development of the area, gives it an ideological colour and attracts pilgrims and tourists from around the world.

Recommended mode of use of cultural heritage site:

1. The use of the object should not harm the physical preservation of the object and should not reduce its historical and cultural value.

2. It is recommended to be used as a nunnery with unobstructed or regulated access of visitors inside the facility. 


\section{References:}

Bevz, M. (2001). Historical cities of Galicia: problems of study and preservation. Notes of the Shechenko Scientific Society. Proceedings of the Commission on Architecture and Urban Planning, 241, 84-112.

Castles and temples of Ukraine: Yazlovets. Retrieved December 15, 2021, from https:// castles.com.ua/ jazlowiec.html

Chen, L. (2013). Temples and monastery complexes in the planning and spatial structure of the town of Buchach. Bulletin of the National University "Lviv Polytechnic": Architecture, 757, 315-320.

Diachok O. (2018). Historical stages of formation and development of architecture of sacred buildings of Ternopil region. Architectural Bulletin of KNUBA: scientific-production collection, 16, 98-108. Kiyv: KNUBA.

Diachok, O. (2017). Architecture of the palace complex in the village of Yazlovets. New achievements of world science: Proceedings of VII International conference. Morrisville, US, Morrisville, Lulu Press.

Diachok, O. (2021). The formation of the architecture of sacred complexes under the influence of social and political processes (on the example of Ternopil region) (Diss.doc.architecture). Lviv Polytechnic National University, Lviv.

Dudarchuk, K.D. (2013). Historical and cultural resources of Ternopil region: the state of preservation and use. Ternopil: V. Hnatyuk TNPU.

Dyomin, M., Dyomina, V., \& Dmitriyev, L. (1995). General principles of documenting monuments of architecture and urban planning in Ukraine. Theory and history of architecture and urban planning, 129-149.

Heritage. Yazlovets. Castle. Retrieved December 10, 2021 from https://m-a-d-m-ax.livejournal.com/340400.html

Horodyskyy, L., \& Zinchyshyn, I. (1998). Journey through Terebovlya and Terebovlyadistrict: Historical essay and guide.Lviv: Kamenyar.

Rudnytskyy, A.M., \& Chen, L.Ya. (2008). The role of monasteries of the rank of St. Basil the Great in the architecture of cities and villages of Ukraine. Bulletin of the National University "Lviv Polytechnic": Architecture, 632, 44-51.

Rybchynskyy, O. (2005). Yazlovets as a town of the Renaissance. Notes of the Shevchenko Scientific Society. Proceedings of the Commission on Architecture and Urban Planning, 70-309.

Ukraine Incognito. Yazlovets. Retrieved December 18, 2021, from https://ukrainaincognita.com/kostoly/yazlovets-chastyna-2-pamyatky-mistechka

Vecherskyy, V. (2008). Ukrainian monasteries. Kyiv: Our time.

Vodzynskyy, E. (1996). Historical cities of Ukraine: research and heritage protection. Architectural Heritage of Ukraine, 3(1), 243-254.

Yazlovets Palace. Yazlovets. Retrieved December 21, 2021, from http://itinery.com.ua/ru/object/view/dvorec-yazlovec 


\section{Appendix}

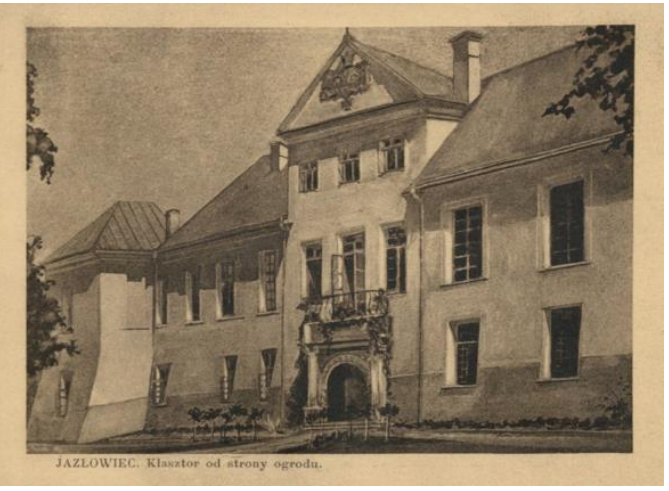

Figure 1. West facade of the palace, photo of 1939 from the archives of the Ternopil Regional Department of Construction and Architecture

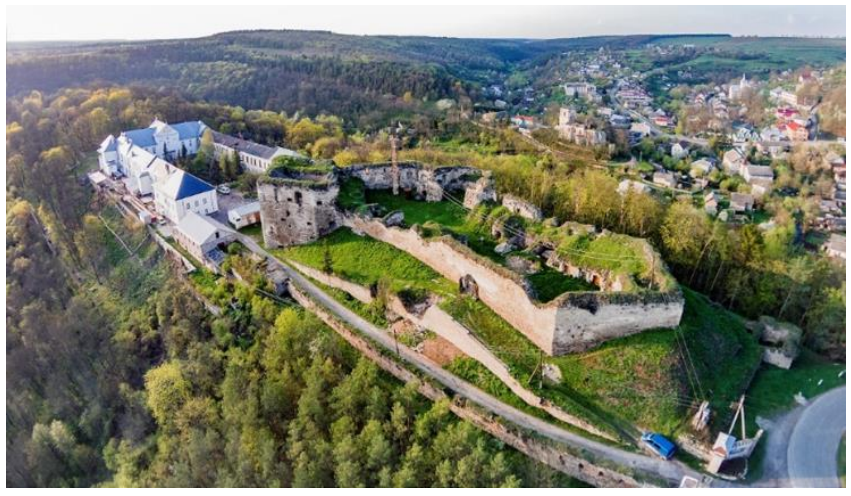

Figure 2. Yazlovets Castle (foreground) and the palace (on the left), view from the southeast. Photos from open sources

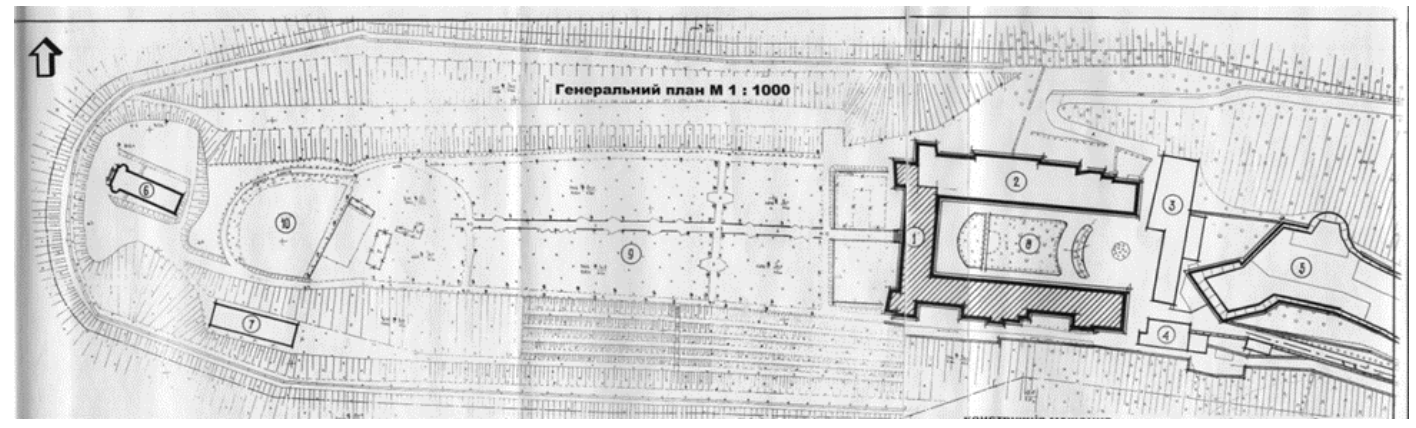

Figure 3. Complex of Yazlovets Palace:

1 - nunnery; 2 - former hospital premises; 3 - utility rooms of the former hospital; 4 - outbuildings of the monastery; 5 - the ruins of the castle; 6 - the tomb of Marcellin; 7 - outbuildings; 9 - palace park; 10 - gardens

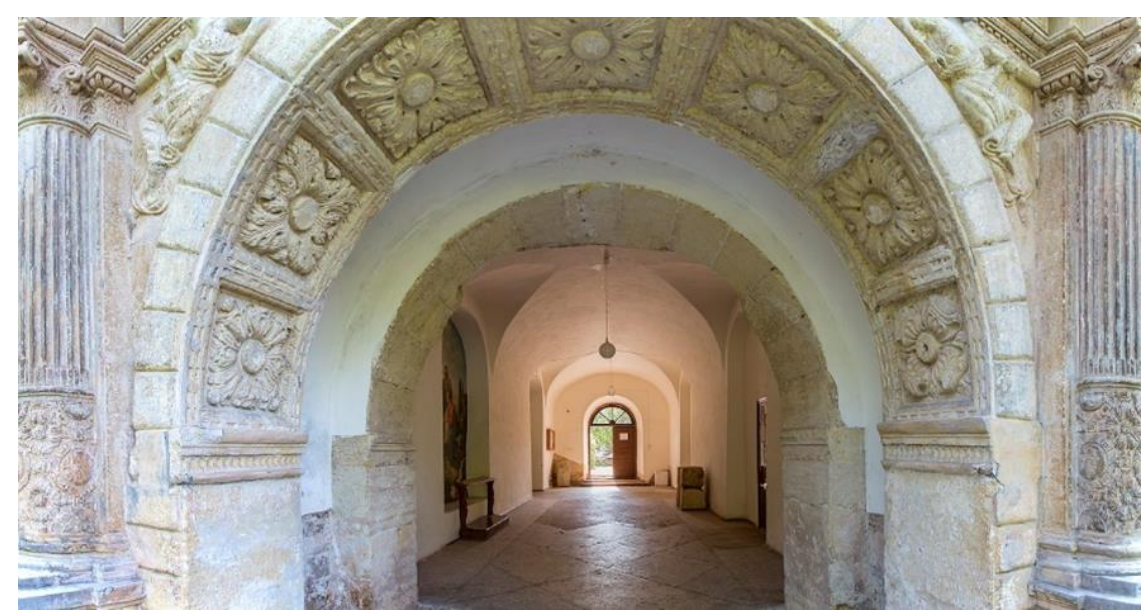

Figure 4. Through passage, view from the west. Photos from open sources 